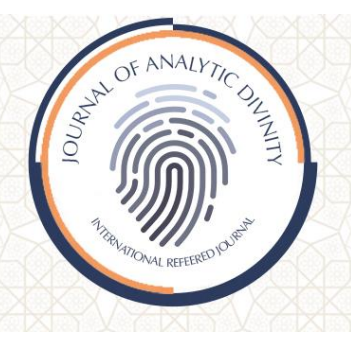

\author{
Journal of Analytic Divinity \\ International Refereed Journal \\ E-ISSN: 2602-3792 \\ Haziran/June 2021/ 5 (2): ss-pp 74-96
}

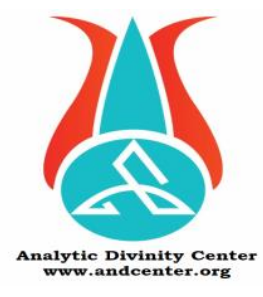

\title{
Cezayirli Yazar Amiş Abdulkâdir'in Hayatı, Eserleri ve Ana Vatanımızdan Hatıra Kalanlar İsimli Hikâyesi
}

The Life and Works of Algerian Writer Amish Abdulkâdir and the Story of Remainders from Our Motherland

\section{Bekir Yıldırım}

Dr., T.C. Millî Eğitim Bakanlığı.

Phd., T.R, The Ministry of National Education

Ankara/Türkiye, akifemre2014@gmail.com

https:/ / orcid.org/0000-0001-2345-6789

Makale Bilgisi | Article Information

Makale Türü / Article Type: Derleme Makalesi / Review Article

Geliş Tarihi / Date Received: 21 Nisan/ April 2021

Kabul Tarihi / Date Accepted: 31 Mayıs/May 2021

Yayın Tarihi / Date Published: 15 Haziran/15 June 2021

Yayın Sezonu / Pub Date Season: Yaz- Haziran/ Summer-June

DOI: $10.46595 /$ jad. 927833

Cite as / Atıf: Yıldırım, Bekir. "Cezayirli Yazar AmişAbdulkâdir'in Hayatı, Eserleri ve Ana Vatanımızdan Hatıra Kalanlar İsimli Hikâyesi", Journal of Analytic Divinity, 5/2 (June 2021): 74-96.

İntihal: Bu makale, iThenticate yazılımınca taranmıştır. İntihal tespit edilmemiştir. Plagiarism: This article has been scanned by iThenticate. No plagiarism detected. Web: http:/ / dergipark.org.tr/jad | e-mail to: editorjand@gmail.com

Copyright ( Published by Özcan Güngör, Ankara Yıldırım Beyazıt Üniversitesi, İslami İlimler Fakültesi / Ankara Yıldırım Beyazıt University, Faculty of Islamic Studies, Ankara-Turkey. Bütün hakları saklıdır. / All right reserved. 
Öz

Amiş Abdulkâdir, 1980'li yıllardan sonra Cezayir edebiyatında kısa öyküleri, roman ve şiirleriyle tanınmış şahsiyetlerden biridir. Yazar anlatılarında Fransızların Cezayir'de yaptıkları katliam ve zulümleri, Cezayir halkının Fransızlara karşı verdiği efsanevi direnişi, Filistin direnişi ve Filistinlilerin yaşadıkları insani dramı (1948-1982) ve Ruslar'ın Çeçenistan'da yaptığı katliamları (1996-1999) ele alır. Ayrıca Şelt şehrinde 1980 yılında meydana gelen yıkıcı deprem ve güncel bir konu olan İslamafobi konularını da eserlerinde işler. Şiirlerinde ise 1990 yılında Cezayir' deki askeri darbe sonrasında çevresindeki bazı yakınlarının kimliği bilinmeyen kişilerce öldürülmesi ve annesinin vefatı konuları yer alır. Amiş Abdulkâdir'in kaleme aldığı ve okuyucuların dikkatini çekmeyi başaran kısa öykülerinden birisi Ana Vatanımızdan Hatıra Kalanlar'dır. Hikâyede Cezayir'in Şelf iline bağlı Tavgirit köyünde Fransız işgalcilerine karşı bağımsızlık mücadelesi veren mücahitlerin direnişi ve sevgilisi Fransız askerleri tarafından elinden alınan Abduh'un cephe hattında sürekli Ayşe'ye özlemi ve onunla aralarında geçen hatıralar ele alınır. Hikâyenin devamında Abduh'un şehit olması ve Ayşe'nin durumu anlatılır. Bu kısa öykü işgale karşı direniş ve sevgiliye özlem mesajlarının verildiği başarılı bir anlatıdır. Yalın ve anlaşılır bir dille kaleme alınan öykü, anlatım teknikleri açısından da oldukça zengin bir niteliğe sahiptir. Yazar dış diyalog tekniği başta olmak üzere iç monolog, betimleme ve geriye dönüş gibi anlatım teknikleriyle tekdüzelikten uzak bir üslup ortaya koyar. $\mathrm{Bu}$ makale Amiş Abdulkâdir'in Ana Vatanımızdan Hatıra Kalanlar öyküsünü teknik ve tematik yönleriyle ele alarak inceler. Ayrıca onun Modern Cezayir Arap Edebiyatında hikâye, roman ve şiir türüne yaptığı katkıları da ele alır.

Anahtar Kelimeler: Amiş Abdulkâdir, Ana Vatanımızdan Hatıra Kalanlar, Kısa Öykü, Modern Cezayir Edebiyatı, Teknik-Tematik İnceleme.

\section{Abstract}

Amiş Abdulkâdir is one of the well-known figures in Algerian literature after the 1980s with his short stories, novels and poems. The writer express in his works, the massacres and atrocities committed by the French in Algeria and the legendary resistance of the Algerian people against the invading French, the Palestinian resistance and the humanitarian tragedy experienced by the Palestinians (1948-1982) and the massacres committed by the Russians in Chechenya (1996-1999). In addition, he mentions the devastating earthquake that occurred in the city of Shelt in 1980 and Islamophobia, which is a current issue. In his poems, after the military coup in Algeria in 1990, some of his relatives were killed by unknown people and the death of his mother. One of the short stories written by Amish Abdulkâdir that succeeded in attracting the attention of the readers is Remainders of Our Motherland. In the story, the resistance of the mujahideen who struggled for independence against the French invaders in the village of Tavgirit in the province of Shelf in Algeria and Abduh, whose lover was taken away by the French soldiers, is constantly longing for Ayşe on the front line and the memories passed between them are remembered. In the continuation of the fiction, the martyrdom of Abduh and the situation of Ayşe are explained. This short story is a successful narrative with messages of resistance against the occupation and longing for the beloved. The story written in a plain and understandable language has a very rich quality in terms of narration techniques. The author creates a style that is far from monotony with expression techniques such as inner monologue, description and back, especially the outer dialogue technique. This article examines Amish Abdulkâdir's story of Remainders of Our Motherland from its technical and thematic aspects. It also discusses his contributions to the genre of story, novel and poetry in Modern Algerian Arabic Literature.

Keywords: Amish Abdulkâdir, Modern Algerian Literature, Remainders of Our Motherland, Short Story, Technical-Thematic Review.

\section{Journal of Analytic Divinity, https://dergipark.org.tr/tr/pub/jad} Volume 5/2 


\section{Giriş}

XVI. yüzyılda Barbaros kardeşlerin aracılığıyla Osmanlı Devleti'nin topraklarına katılan yaklaşık üç yüzyılı aşkın Osmanlı hâkimiyetinde kalan İslam coğrafyasının bir bölümümü oluşturan Cezayir, XIX. yüzyıl başlangıcından itibaren Fransa'nın işgaline maruz kalır. ${ }^{1}$ Fransa, 1830-1962 yılları arasındaki işgali döneminde Cezayir' in kültürel kimliğini yok etme, halkı İslam'dan uzaklaştırarak Hristiyanlaştırma, fakirleştirme, cahil bırakma, Arapçayı yasaklama ve işlevsiz hale getirme gibi çeşitli politikalar yürütür. Bu uygulamalar Cezayir'de Arapçanın eğitim ve öğretimini geriletse de onu tamamıyla ortadan kaldiramaz. ${ }^{2}$

Cemiyyetu'l-Ulemâi'1-Muslimîn ve Hizbu'ş-Şa'b tarafından kurulan medreseler, halk arasında Arapçanın varlığını sürdürme ve muhafaza edilmesinde bariyer görevi üstlenir. ${ }^{3}$ Ülkenin bağımsızlığından sonra resmi dilin Arapça olmasıyla birlikte Arapça edebi eserlerde artış meydana gelir. Bu bağlamda roman, şiir ve hikâye türünde eserler telif eden yazarlar ortaya çıar.

Öykü türündeki eserler genellikle Fransız işgaline direnişi konu edinir. Bu öyküler hem halkın milli şuur kazanmasına vesile olur hem de dünyaya Fransız işgalinin yaptığı tahribatları duyurur. Ayrıca sosyalist ideolojiyi taşıyan öyküler ortaya çıktığı gibi toplumsal konuları elen alan eserler de görünmeye başlar. Böylece Cezayir'de öykü olgunlaşır, Arap ve Batılı muadilleriyle yarışmaya başlar. ${ }^{4} \mathrm{Bu}$ alanda Muhammed b. Âbid el-Celâlî, Ahmed Bin Âşûr, Ahmed Rıza Hûhû, Muhammed Said ez-Zahirî ve Ebu'l-Kâsım Sa' dalla ${ }^{5}$ gibi isimlerin yanı sıra Said Butacin, Zehra Dik, Muhammed Emin ez-Zavi, Râbih Haddûsî, Umer b. Kîne, Abdulmelik Murtâd gibi kişiler eserler verir. ${ }^{6}$

İlk Arapça romanlar 1960'lı yılların sonlarına doğru ve 1970'lerin başlarında ortaya çıkar. Uzun süren işgal nedeniyle doğal olarak metinler içerik bakımından Fransız edebiyatıyla etkileşim halinde olur. Bu romanlar daha çok sömürge dönemindeki acı tecrübeler ile bağımsızlık için yapılan ulusal mücadeleyi işlerler. Bu romanlarda Cezayirlilerin tarihsel, dilsel ve kültürel kökleri bakımından yeniden özüne dönmesi amaçlanır. Ayrıca İslami temaların yer aldığı çalışmalar da göze çarpar.7 Roman alanında Muhammed 'Ali ‘Arar, Mirzâk Bektâş, edebiyat dünyasına giren isimlerdendir. 1980'lerden

\footnotetext{
1Adil Baktıaya, “1830: Fransa'nın Cezayir'i İşgali, Abdülkadir'in Yükselişi ve Amerikan Kamuoyunda Abdülkadir Hayranlığı", Ortadoğu Etütleri 1/2 (Ocak 2010), 147.

2 Metin Parıldı, "Fransız Sömürgeciliği Döneminde Kuzey Afrikada Arap Dili ve Edebiyatına Genel Bakış", Bilimname 8 (Ocak 2010), 116-117.

3Sabri Hizmetli, “Osmanlı Yönetimi Döneminde Tunus ve Cezayir'in Eğitim ve Kültür Tarihine Genel Bir Bakış”, Ankara İlahiyat Fakültesi Dergisi 32 (1991), 15-16.

4Turgay Gökgöz, Modern Cezayir Edebiyatı (İstanbul: Akdem Yayınları, 2019), 245.

${ }^{5}$ M. Kılay Araz, "Cezayir Edebiyatında Kısa Öykü", Nüsha 20/50 (Haziran 2020), 168.

${ }^{6}$ Gökgöz, Modern Cezayir Edebiyat, 245.

7 Gökgöz, Modern Cezayir Edebiyatı, 303-304.
} 
sonra ise Cîlâli Hallâs, Vâsânâ el-A'rac el-Hâşimî Sa'idânî, Ahlâm Müsteğânimî ve İbrâhim Sa'dî, Emin Zâvî, Muhammed Sârî, el-Hîb es-Sâyîh, Hamide Ayyâşi, Râbih Haddûsî gibi isimler göze çarpar. 1990'lı yıllarda Beşîr Mufdî, Yâsemin Sâlih, Fadîle Fârûk, Cemîle Zenîr en önemli isimler arasında yer alır. ${ }^{8}$

Cezayir şiirinin şekil almasında kuşkusuz Mısır'da ortaya çıkan Divan ve Apollo ekolleri $^{9}$ ile Amerika' da oluşan Mehcer edebiyatının ${ }^{10}$ tesiri bulunmaktadır. Şiir daha çok bağımsızlık, birlik olma, ıslah ve emperyalizme direnme hususlarında önemli bir araç olmuştur. İlerleyen süreçte şairler, Arap halklarının krizlerini, uyanışlarını ve İslamî temalı konuları ele almışlardır. ${ }^{11}$

Şiir alanında öne çıkan kişiler olarak 'Abdul'âlî Rezzâkî, Mahmûd b. Meryûme, Ahlâm Müsteğânimî, Zeyneb el-A'vec, Rukiye Hedrîs, 'Ayyâş Yahyâvî, Beşîr Kaytûn, elAhdar Fellûs, 'İzzeddîn Mîhûbî, 'Ammâr b. Miryâş, Rîma 'İlâk, el-Fîrûzî (el-Ezher) 'Acîrî, Nâsira Mumammedî ve Mey Gû̂l zikredilebilir. ${ }^{12}$

Modern Cezayir edebiyatında yukarıda zikredilen kişiler dışında başka yazarlar de bulunmaktadır. Bunlardan birisi de Amiş Abdulkâdir'dir. Yazar ülkemizde fazla tanınmayan, fakat ülkesinde 1983 yılında Vizâratu't-Ta'lîmi'l-'Âl̂ ve'l-Bahsi'l-'Ilmî̀ ve Mecelletu's-Sekâfe ve's-Sevra'nın ortaklaşa düzenlediği kısa hikâye yarışmasında Ve Mâ Teyessera min Zâkira Ümmine'l-Erz “وما تسير من ذاكرة أمنا الأرض" Ana Vatanımızdan Hatıra Kalanlar isimli hikâyesiyle birinci olan bir müelliftir. Ayrıca Öykü, roman, şiir ve edebi türlerde eserleri bulunan bir kişidir. Yazar ulusal ${ }^{13}$ ve diğer Arap ülkelerinin medyalarında zaman zaman gündeme gelmektedir. ${ }^{14}$ Ayrıca Cezayir ulusal televizyonunda onunla röportajlar yapılmıştır. ${ }^{15}$ Yine yazarın Beyâzu'l-Yakîn romanıyla ilgili Arcûn el-Bâtûl tarafından yapılmış Amiş Abdulkâdir fî Beyâzi'l-Yakîn min Rivâyeti't-Tecrube ilâ Rivâyeti't-Tecrîb isimli bir çalışma bulunmaktadır. ${ }^{16}$

\footnotetext{
8 Gökgöz, Modern Cezayir Edebiyatı, 301.

${ }^{9}$ Divân ekolü XIX. asrın ikinci yarısı ile XX. asrın birinci yarısında Abbas Mahmud el-'Akkad, İbrâhîm Mâzinî ve Abdurrahman Şukrî tarafından kurulmuştur. Şiirde yeniliği benimseyen Divân ekolünün en nemli görüşleri şu şekildedir: Şiirin mevzularında bir yenilik meydana gelmeli, şair duygularını ifade ederken taklit ve donukluktan kaçınmalı, yenilikçi modern Arap şiirinde eski Arap şiirinin yanında Batı edebiyatından istifade edilmeli, duyguların yoğun olarak dile getirildiği şiire büyük bir ehemmiyet gösterilmelidir. (Detaylı bilgi için bkz: Ousama Ekhuar-Eyüp Sevinç “Modern Arap Şiirinde Medresetu'd-Divân'ın Teori ve Pratiği Arasındaki Çelişkiler", Fırat Üniversitesi Illahiyat Fakültesi 22/1 (2017), 87.

10 Modern Arap şiirinin “yenileşme” sürecinde önemli bir dönüm noktasını oluşturan Apollo Grubu, 1930'lu yıllarda Arap şiirine egemen olan edebî bir oluşumdur. Bir şair ve eleştirmen olan Mısırlı Ahmed Zekî Ebû Şâdî (1892-1955)'nin girişimleriyle oluşan bu grup, Kuzey Amerika'daki göçmen şairlerin etkisiyle romantik bir edebiyat anlayışına sahipti. (Detaylı bilgi için bkz: Derya Adalar Subaşı, “Apollo Grubu Bir Modern Arap Şiiri Ekolü", Ankara Üniversitesi Dil ve Tarih-Coğrafya Fakültesi Dergisi 47/2 (2007), 61-81.

11Parıldı, "Fransız Sömürgeciliği Döneminde Kuzey Afrikada Arap Dili ve Edebiyatına Genel Bakış", 123.

12Gökgöz, Modern Cezayir Edebiyatı, 193-227.

13 et-Tahrîr, "el-Ustâz Amiş Abdulkâdir li't-tahrîr" (20 Eylül 2014), 17.

14 eş-Şerku'l-Evsat Cerîdetu'l-Arabi'l-Duveliyye, “Devriyyât" (30 Kasım 2003).

15Youtube, "Profesör Amiş Abdulkâdir fî Hissat-i likâi'l-Ma' rife bi'1-Kanâti'l-Vataniyyeti'1- Cezâiriyye” (Erişim 20 Mart 2021); "Profesör Amiş Abdulkâdir el-Cuz 4" (Erişim 20 Mart 2021).

${ }^{16}$ Arcûn el-Bâtûl, Abdulkâdir Amiş fî beyâzi'l-yakîn min rivayeti't-tecrübe ilâ rivâyetit-tecrîb (Cezayir: elCâhiziyyetu's-Sekâfiyyetu'l-Cemiyye, 2008).
}

Journal of Analytic Divinity, https://dergipark.org.tr/tr/pub/jad Volume 5/2 
Modern Cezayir edebiyatıyla ilgili ülkemizde yapılan çalışmalar:

1- $\quad$ Metin Parıldı tarafından Fransız Sömürgeciliği Döneminde Kuzey Afrika'da Arap Dili ve Edebiyatına Genel Bakış isimli bir makale kaleme ele alınmıştır. Bu makalede Fransa'nın Arap dilini ortadan kaldırmak için yaptığı uygulamalar, Modern Cezayir edebiyatında nesir, şiir alanında yapılan çalışmalar ve müellifleri ele alınmış, fakat araştırmanın konusu olan Amiş Abdulkâdir'den hiç bahsedilmemiştir.

2- Cezayir Edebiyatında Kısa Öykü isimli çalışma Mehmet Ali Kılay Araz tarafından yapılmıştır. Bu çalışmada Cezayir kısa öyküsünün gelişim süreci ve bu dönemi etkileyen şartlar ele alınmış, fakat yazıda Amiş Abdulkâdir'e yer verilmemiştir.

3- $\quad$ Sabri Hizmetli tarafından hazırlanan Osmanlı Yönetimi Döneminde Tunus ve Cezayir'in Eğitim ve Kültür Tarihine Genel Bir Bakış isimli çalışmada Osmanlı dönemi ve Fransız işgaliyle başlayan süreçte bu ülkelerdeki eğitim ve öğretimle ilgili çalışmalar ve yazarlar ele alınmıştır. Amiş Abdulkâdir ile ilgili herhangi bir bilgi yer almamaktadır.

4- $\quad$ Turgay Gökgöz tarafından Modern Cezayir Edebiyatı isimli bir eser kaleme alınmış, çalışmada Modern Cezayir edebiyatında şiir, öykü, roman ve yazarları incelenmiş Amiş Abdulkâdir hakkında herhangi bir bilgi verilmemiştir.

Bu araştırmada şu sorulara cevap verilmeye çalışılmıştır: 1- Amiş Abdulkâdir kimdir? Hangi edebi türlerde eserler sunmuştur? 2- Eserlerinde hangi konulara ağırlık vermiştir. 3Ana Vatanımızdan Hatıra Kalanlar isimli hikâyesinin tematik özelliği nedir?

\section{Amiş Abdulkâdir, Hayatı ve Eserleri}

Amiş Abdulkâdir, 1950 yılında Cezayir'in Şelf iline bağlı Tavgirit kasabasında dünyaya geldi. İlkokul, ortaokul ve lise eğitiminden sonra 1978-1979 yılları arasında ilkokul öğretmenliği yaptı. 1983 yılında Vehrân Üniversitesinden mezun oldu. 1984-1998 yılları arasında ilkokul öğretmenliği yaptı. 1994 yılında yüksek lisans eğitimini Kıssatu't-Tifl fi'lCezâir isimli teziyle tamamladı. Bu çalışma daha sonra kitap olarak basıldı. 1998 yılında Tiaret şehrindeki İbn Haldun Üniversitesinde öğretim görevliliğine başladı. 2000-2002 yılları arasında Şelf Üniversitesinde Arap Dili ve Edebiyatı bölüm başkanlığı yaptı. 2003 y1lında Edebiyetu'n-Nas fî Kitâbât-i Eb̂̂̀ Hayyân et-Tevhîdî isimli teziyle Vehrân Diller Üniversitesinde doktorasını tamamladı. 2009 yılında profesör oldu. 2000-2011 yılına kadar Şelf' deki Hasibe b. Ali Üniversitesinde öğretim görevliliğini sürdürdü. 2011 yılında Ahmed Zabane Üniversitesinde ders vermeye başladı. Yazar hâlen bu üniversitede profesör olarak görevine devam etmektedir.

Cezayir'de Cerîdetü'n-Nasr, en-Nâdi'l-Edebî bi Cerideti'l-Cumhûriyye ve Cerîdetü'ş-Şa'b isimli dergilerde makaleler yazdı. Yazarın bazı makaleleri ayrıca Lübnan'daki Kitâbâtu'lMu'âsırati'l-Lübnaniyye isimli dergide yaymland1. Vizâratu't-Te'lîmi'l-'Âlîve'l-Bahsi'l-'ilmîve 
Mecelletu's-Sekâfe ve's-Sevra'nın 1983 yılında ortaklaşa düzenlediği kısa hikâye yarışmasında Ana Vatanımızdan Hatıra Kalanlar isimli hikâyesiyle birinci oldu. Bu hikâye, yarışmayı organize eden Mecelletu's-Sekâfe ve's-Sevra dergisi tarafından 1983 yılında derginin 9. sayısında yayınlandı. Daha sonra bu "Dâiratu'l-Mahdû'în" isimli kitabına ilave edilmiştir. ${ }^{17}$

Yazarın eserleri hikâye, şiir ve roman gibi çok çeşitli türlerden oluşmaktadır. Eserlerindeki bu çeşitlilik yazarın edebi yönünün kuvvetli olduğuna işaret etmektedir.

\subsection{Hikâyeleri}

Yazar, hikâyelerini "Kanâdîlu'z-Zalâm" Karanlığın Kandilleri ve "Dâiratu'lMahdû'în" Aldatılanların Kısır Döngüsü isimli eserlerinde toplamıştır.

\section{1. "Kanâdîlu'z-Zalâm"18 Karanlı̆̆ın Kandilleri'ndeki Hikâyeler:}

a. "Zâkiratu'ş-Şehâde" Şehitliğin Hatırası adlı hikâyede yazar, arkadaşı Hüseyin ve direnişçilerin Fransız işgaline karşı verdiği mücadeleleri, Fransızların Cezayir' de yaptığı katliamları ve Hüseyin' in şehitliğini anlatır. Muhtemelen arkadaşından şehitlik dişında bir şey kalmayınca müellif hikâyenin ismini "Zâkiratu'ş-Şehâde" olarak isimlendirmiştir.

b. "ez-Zemenu'l-Kâkî" Askerin Tasallutu isimli hikâyede Salih Lübi Nida isimli bir Filistinli ve Filistinli direnişçilerin İsrail işgaline karşı mücadeleleri anlatılır. Ayrıca işgal sonrası oluşan felaket ve memleketlerinden göçmek zorunda kalanların dramı Salih Lübi Nida ve benzerleri üzerinden ele alınmaktadır.

c. “Zebîbetu'l-Mevt" Ölüm Kabarcı̆̆ı ve "eş-Şerh" Yarık hikayelerinde İslam'a ait secde izi, sakal, takke ve tesbih gibi bazı semboller nedeniyle bazı müslümanların teröristlikle suçlanması ele alınmakta ayrıca bu kişilerin işini, çevresini kaybetmesi ve hapse düşme süreçleri işlenmektedir.

2. "Dâiratu'l-Mahdû'în" Aldatılanların Kısır Döngüsü19 eserinde geçen ve "Ve Mâ Teyessera min Zâkirat-i Ummine'l-Erz" Ana Vatanımızdan Hatıra Kalanlar isimli hikâyesi, bu araştırmada müstakil bir bölüm olarak ele alındığı için burada sadece isminin zikredilmesiyle yetinilecektir. Bu eserde geçen diğer hikâyeler:

a. "Efrâh fi'n-Nâr "Ateşteki Civcivler: Hikâyenin ana kahramanı, içinde patlayıcının olduğu bir kutuyla dolaşan ve Fransız askerlerini gördüğünde sigara diye bağıran bir kişidir. Bu direnişçi bir gün Fransız askerlerinin uğrak yeri olan bir meyhaneye girer. Orada çalışanlardan birine elindeki kutuyu verir. Kutuyu alan şahıs onun meyhaneden çıkmasını ister. Onun akabinde kutuyu alan garson da çıkar. Biraz sonra kutu patlar. Onlarca Fransız

\footnotetext{
17Amiche Abdelkader, "es-Sîratuz'-Zâtiyyetu'l-İlmiyye li'l-Ustâz Abdulkâdir Amiş", Facebook (8 Mayıs 2021, 23:30).

18Amiş Abdulkâdir, Kanâdîlü'z-zalâm (Hervan: Daru'l-Garb, 2004).

${ }^{19}$ Amiş Abdulkâdir, Dâiratü'l-mahdû'în (Cezayir: el-Muessesetu'l-Vataniyye li'l-Küttâb, 1986).
}

Journal of Analytic Divinity, https://dergipark.org.tr/tr/pub/jad Volume 5/2 
askeri ölür ve yaralanır. Yazar, kanaatimizce Cezayirli direnişçilerin yaptığını ateş içindeki civcivlere benzetmektedir.

b. "es-Sadâ" Yankı: Hikâyedeki olay 1962 yılının Mart ayında Tavgirit köyünde geçmektedir. Bir tepede toplanıp Fransız askerlerini gözetlemeye başlayan ve onlara saldıran direnişçilerin hücumu anlatılmakta ve saldırıdan haberdar olan köy kadınlarının zılgıt eşliğinde sevinçleri sunulmaktadır. Mücahitlerin saldırısının köyde yaptı̆̆ı tesiri yazar muhtemelen bir yankıya benzetmiş bu nedenle hikâyeye bu ismi vermiş olabilir.

c. "Hâze'l-Hub İbni'ş-Şems" Güneşin Oğlunun Sevgisi: Cezayir'in bağımsızlığından önce Fransızların Cezayirlilerden atadığı valilerin zulmü anlatılmaktadır. Bu kişiler kendi topraklarını yabancılara karşı savunmak yerine direnişçilere ve halkı direnişe davet eden aydınlara karşı saldırıda bulunmaktadırlar. Yazar bu kişilerin vatan sevgisini yakan güneşe benzetmektedir.

d. "İş'âlu'z-Zâkirati'l-Medîne" Şehrin Hatırasını Canlandırma: Öyküde Esnam şehrini depremden sonra terk eden ve şehrin yakınlarına çadır kuran bir karı kocadan bahsedilmektedir. Kadın ve kocası arasında deprem esnasında orada kalan oğullarının durumuyla ilgili diyalog geçmektedir.

e. "ez-Zilzâl" Deprem: Hikâyede ismi zikredilmeyen bir adamın 1980 yılında Cezayir' in Asnam ${ }^{20}$ şehrinde meydana gelen depremi anlatması zikredilir. Bu kişi deprem nedeniyle insanların bir kısmının enkaz altında öldüğünü, bazılarının yaralandığını, bir bölümünün kurtulduğunu ifade etmektedir. Kurtulanların halini mahşerdeki insanların koşuşturmacasına benzetmektedir.

f. “Dakîkatu'l-Huzn” Hüzün Anı: Kıssadaki olaylar Filistin ve Lübnan'daki Sabra ve Şatilla kamplarında geçmektedir. Arab yöneticilerinin Filistin ve Kudüs davası, Sabra ve Şatilla' daki katlimlara ${ }^{21}$ duyarsızlıkları ele alınmaktadır. Arap liderlerin sloganla bu konulara sahip çıktıklarını, gerçekte ise İsrail ile işbirliği yaparak direnişçileri kötü göstermeye çalıştıkları anlatılmaktadır.

g. "Dâiratu'l-Mahdû'în” Aldatıların Kısır Döngüsü: Hikayenin konusu 1948 yılında İsrail'in kurulması sonucu Batı Şeria'daki topraklarından olan ve sürekli oralara tekrar dönmeyi arzulayan bir ailenin beyi ve hanımı arasında geçen diyaloglardan oluşmaktadır. Hikâyede sık sık Yahudilerin " "محد مات فخلف بنات"Muhammed öldü geriye kızları bıraktı sözleri hanım tarafından dile getirilmektedir. Yine Arap yöneticilerin Filistin'i sattığı da sıkça dillendirilmektedir.

20T.C. İçişleri Bakanlığı Afet ve Acil Durum Yönetimi Başkanlığı Deprem Dairesi Başkanlığı/Afad, "10 Ekim 1980 Cezayir Depremi" (Erişim 16 Ocak 2021).

${ }^{21}$ Diyanet İşleri Başkanlığ1/diyanethaber, "Sabra ve Şatilla Katliamı" (16.01.20121) . 


\subsection{Romanları}

“ez-Zemenu's-Sa'b" Zor Zaman'22: Romanda, Fransa'nın zulümleri neticesinde kırsaldan Şelf vilayetinin Tavgirit köyüne sığınmak zorunda kalan bir ailenin yaşadığ1 zorluklar ele alınmaktadır. Olaya konu olan aile, Fransa'nın yaptığı zulümler ve fakirlikle mücadele etmektedir. Bu ailenin erkeği hayatta olmadığ 1 için sorumluluk annenin üzerine kalmıştır. Annenin Hasayin isminde bir oğlu vardır. Bir gün annesi onu dağdaki mücahitlerin yanına götürür. Onun hayali, oğlunun da yer aldığ1 direnişçilerin zafere ulaşmasıdır. Fakat çocuğu şehit olduğu için annenin bu hayali gerçekleşmemiştir.

"Beyâzu'l-Yakîn" Hakikatin Kesinliğiż: Yazar, bu eserini Fransız kanalı Tv5'de Çeçenistanlı bir kıza yapılan işkenceleri anlatan haberi izledikten sonra yazmıştır. Romanın başkahramanı Çeçenistanlı kız, Haydî́ dir. Bu kişi Rus askerleri tarafından vücudunda sigara söndürme dâhil farklı işkence türlerine maruz bırakılmıştır. Yazar eserinde Haydi'yi hayalinde canlandırarak Cezayir' deki üniversitelerde okutmaya çalışmaktadır.

“Sukût... el-'Ârife İzâbel Tetehaddes "Sessizlik... Bilge İzabel Konuşuyor24: Eserde Cezayir benim vatanım diyen Fransız muhabir İzabel'in hayatı ve onun karşılaştı̆ğ bazı kişilerle arasında geçen olaylar anlatılmaktadır. Romanın başkahramanı İzabel yedi dil bildiği için romanda Arapça dışında Amazika, Türkçe, Fransızca gibi dillerden zaman zaman kelimeler ve ifadeler yer almaktadır. Müellifin bu eseri de "Beyâzu'l-Yakîn" gibi hayalin gerçeğe dönüşmesine dayanmaktadır.

\section{3. Şiirleri}

"'Avâu's-Sadâ" Yankının Çı̆̆ğğg25 isimli şiir kitabı, 1992 yılında Cezayir iç savaşı neticesinde herhangi bir sorumluluğu olmayan amcasının ve yakınlarının barbarca katledilmesi üzerine yazılmış mersiyeleri içerir.

"'Afven... Seahmil Kaderî ve Esîr" Pardon... Alın Yazımı Taşıyorum ve Yürüyorum²6 adlı eser annesinin ölümü üzerine yazmış olduğu mersiyeler ve sevgi konusunu içeren şiirlerden oluşmaktadır.

\subsection{Diğer Kitapları}

"Kıssatu't-Tifl fi'l-Cezâir" Cezayir'de Çocuk Hikâyeciliğiziz bu kitap klasik dönem Arap edebiyatı ve Cezayir' de çocuk edebiyatının geçirdiği merhaleleri ele almaktadır. Eserde çocuk edebiyatında dini, ahlaki ve mili konuların nasıl işlenmesi gerektiği üzerinde

\footnotetext{
22Amiş Abdulkâdir, ez-Zemenü's-sa'b (Hevran: Dâru'l-Ğarb, 2003).

${ }^{23}$ Amiş Abdulkâdir, Beyâzu'l-yakîn (Vehrân: Menşûrâtü'l-Dâri'l-Edîb, 2006).

${ }^{24}$ Amiş Abdulkâdir, Sukût... el-Ârife İzabel tetehaddes (Cezayir: Tizi Vuzu Dâru'l-Emel lit-Tibâ'a Ve'n-Neşr, 2019).

${ }^{25}$ Amiş Abdulkâdir, 'Avâü's-sadâ (Vehrân: Dâru'l-Ğarb, 2004).

${ }^{26}$ Amiş Abdulkâdir, Afven... seahmil kaderî ve esîr (Cezayir: Tizi VuzuDâru'l-Emel lit-Tibâ'a Ve'n-Neşr, 2012).

${ }^{27}$ Amiş Abdulkâdir, Kıssatü't-tıflfi'l-Cezâir (Cezayir: Dâru'1-Ğarb, 2003).
} 
durulmaktadır. Ayrıca kıssalarda çocuklara hitabın nasıl olacağı ve onların dil yeteneğinin gelişmesi için nasıl bir yöntem uygulanacağı ele alınmaktadır.

\subsection{Yazarın Eserlerinde Ele Aldı̆̆ı Konular:}

Yazarın roman ve hikâyelerinde ele aldığı konular, Fransızların Cezayir'deki işgaline karşı direniş ve Fransızların yaptıkları zulümler, Filistin direnişi ve Filistinlilerin dramı (1948-1982), Ruslar'ın (1996-1999) yılları arasındaki Çeçenistan'daki katliamları, bağlı olduğu Şelt şehrinde 1980 yılında meydana gelen yıkıcı deprem ve güncel bir konu olan İslamafobidir. Şiirlerinde ise 1990 yılında Cezayir'de askeri darbeden sonra çevresindeki bazı yakınlarının kimliği bilinmeyen kişilerce öldürülmesi ve annesinin vefatı karşısında duyduğu hüzün yer almaktadır.

Fransız işgalinin hüküm sürdüğü dönemlerde yaşaması, zulümlere tanık olması ve bağımsızlık sonrası insanlar arasında Fransız işgalinin ve direnişin çok konuşulması gibi nedenlerden dolayı yazarın, direniş konusu olan çalışmalara ağırlık verdiği söylenebilir. Zannımızca kendinde oluşan direniş kültürü, yazarı diğer bölgelerdeki bağımsızlık hareketlerine yöneltmiştir. Buna paralel olarak Filistin direnişi ile Filistin ve Çeçenistan'da yapılan zulüm ve katliamlara ilgi duymuştur denilebilir. Ayrıca yaşanan acıların yazarı duygusallaştırdığı bu nedenle şiirlerinde hüzün konularını öne çıkardığı da düşünülebilir.

\section{2. "Ana Vatanımızdan Hatıra Kalanlar" Adlı Kısa Öykünün Teknik-Tematik İncelemesi}

\subsection{Hikâyenin Konusu}

Öykünün konusu, Cezayir' in Şelf28 iline bağl1 Tavgirit ${ }^{29}$ köyünde Fransız işgalcilerine karşı bağımsızlık mücadelesi veren mücahitlerin direnişidir. Sevgilisi Fransız askerleri tarafından elinden alınan Abduh'un cephe hattında sürekli onu düşünmesi ve aralarında geçen hatıralar; Abduh'un şehit olmasından sonra ise sevgilisi Ayşe' nin yaşadığı dramatik durum eserde anlatılmaktadir.

\subsection{Hikâyedeki Şahıslar}

Hikâye ve roman gibi edebî türlerde şahıslardan kastedilen, bu anlatılarda yer alan kişilerdir. Öyküde aktarılan olay örgüsünün eksiksiz olabilmesi için olaya dâhil olan insanlar ve bu insanların farklı yönleriyle ortaya konulması gerekir. 30 "Ana Vatanımızdan Hatıra Kalanlar", Abduh başta olmak üzere barındırdığı farklı insan tipolojileri ve bunların

\footnotetext{
${ }^{28}$ Wikipedia, "Şelf Vilayeti" (16 Ocak 2021).

29Wikipedia, "DâiraTavgirît" (16 Ocak 2021).

30Mücahit Küçüksarı, "Suriyeli Öykücü Sa'îdHûrâniyye ve Ahî Rafîk (Ağabeyim Refik) Adlı Kısa Öyküsü”, Necmettin Erbakan Üniversitesi İlahiyat Fakültesi Dergisi 50/50 (Ocak 2020), 57-80.
} 
zengin gözlem ve tasvirlerle okuyucuya tanıtıldığı kısa bir öyküdür. Buna göre öyküde yer alan kişiler ve genel özellikleriyle ilgili olarak şu bilgileri vermek mümkündür:

\subsubsection{Abduh}

Hikâyenin ana kahramanı, hem direnişçi kimliğiyle öne çıkmakta hem de Fransız askerlerinin, elinden aldığı sevgilisi Ayşe'ye özlemiyle dikkat çekmektedir. Cephe hattında sürekli zihninde Ayşe'nin olduğu görülmektedir. Hikâyedeki şu ifadeler onun bu halini veciz bir şekilde özetlemektedir:

$$
\begin{aligned}
& \text { عائشه في ايدي الهمجيين ؟!. } \\
& \text { تموج في داخله شيء حار ؛و انفجر باعماقه صوت حاد }
\end{aligned}
$$

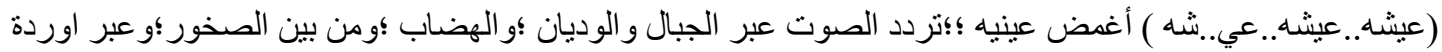

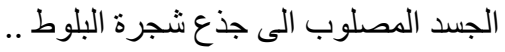

"Ayşe barbarlarn elinde. İçinde yanı tutuşan bir şey kabardı ve yüksek bir ses patladı. (Ayşe.. Ayşe.. Ay şe) gözünü kapattı. Ses vadiler ve dağlar, tepeler ve kayalar ve palutağactnın köklerine asılmış cesed boyunca yankılandı.."

Abduh'un Vietnam savaşında yer aldığı ve orada savaş taktikleri öğrendiği anlaşılmaktadır. Hikâyedeki şu cümleler bunu teyit etmektedir:

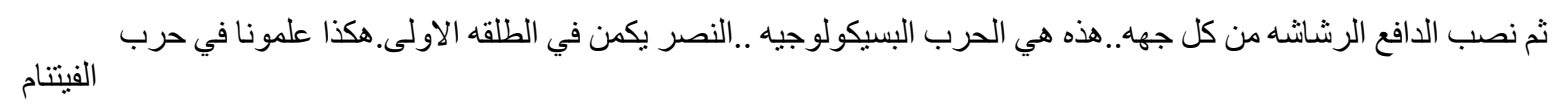

Her tarafa makinalı tüfek kurdu. Bu psikolojik savaştı. Illk atışta zafer olabilir. Bunu bize Vietnam harbinde öğrettiler.

Abduh'un kendisini ülkesi ve sevdiği Ayşe' ye adadığı görülmektedir:

$$
\text { ( الجزائر دين في عنقي .عائشه دين في عنقي ياعلي يا خويا ) }
$$

(Cezayir boynumda borçtur. Ey Ali! Ey Huya! Ayşe boynumda borçtur... )

\subsubsection{Ali}

Abduh'un yanındaki direnişçidir. Bu şahıs, daha çok silahıyla ve Fransız askerlerini gözetlemekle meşgul olmakta, ara sıra Abduh'a sorular sormakta ve Abduh ona cevap vermektedir. Silahıyla meşgul olmasına örnek:

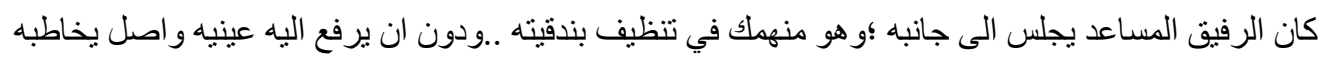


Yanında yardımcı arkadaşı oturuyordu. O tüfeğini temizlemeye kendini kaptırmıştı.

Abduh'a soru sormasına örnek:

وناول عبده واحدة بعد ان اضرمها هي الاخرى..

ألازلت تحبها ياعبده؟

Bir diğerini yaktıktan sonra bir tane Abduh'a verdi.

-Ey Abduh, onu hala sever misin?

\subsubsection{Ayşe}

Abduh'un sevgilisi ve evlenmek için hayal kurduğu kişidir. Fakat Fransız askerlerinin onu alıp götürmeleriyle Abduh'un hayali suya düşmüştür. Ayşe'nin de Abduh'u çok sevdiği şu ifadelerden anlaşılmaktadır:

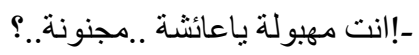

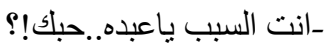

-Ey Ayşe sen aptalsın, mecnunsun!-Sen sebep oldun Ey Abduh senin sevgin!

Ayşe'nin Abduh'u kaybetmesi nedeniyle akıl dengesini kaybettiği anlaşılmaktadır. Buna işaret ise şu cümlelerdir:

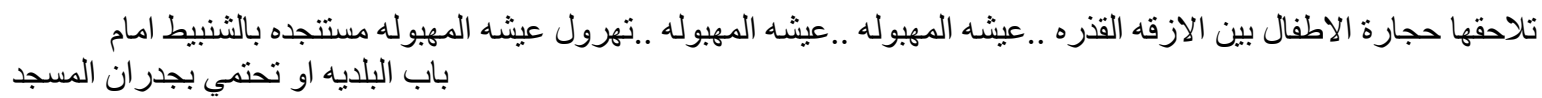

Eski geçit arasında çocukların taşları onu (Ayşe'yi) izliyor... Îşe aptal.. I̧şe aptal.. Aptal Ayşe Belediyenin kapısı önünde zabıtalardan yardım isteyerek koşuşturuyor veya mescidin duvarlarnna siğınıyor...

\subsubsection{Frans1z Askerleri}

Cezayir'i işgal için gelen Fransız askerleri hikâyede her şeyi yiyip bitiren vahşi çekirgelere benzetilmektedir. Ayrıca çatışma esnasında ölen Fransız askerlerin çığlık sesleri zikredilmektedir. Fransız askerlerini anlatan ifadeler:

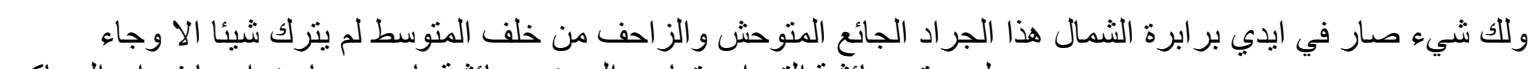
عليه حتى عائشة التي احبيتها حد الموت .. عائشة ياعبده صارت لئرت ايضا في ايد العساكر. 
Bir şeyin vardl, o barbar kuzeylillerin (Fransızlar) elinde. Bu aç gözlü, vahşi, orta Avrupa'dan (Fransa) gelen çekirge hiçbir şey bırakmadı ve aldı. Ta ki ölümüne sevdiğin Ayşe'ni de...

$$
\text { تفجرات وشلال من الفرقعات القاتلة ور عود عاقرة .ضالة ..واخير اسقوط اشياء مبهمة .واستغاثة العساكر و.....و.....و }
$$

Peş peşe öldürücü patlamalar, semeresiz gök gürültüleri... Hedef.. Sonunda ne olduğu bilinmeyenlerin düşüşü. Ve askerlerin yardım çığglı̆̆ ve..... ve.....ve.....

\subsubsection{Mücahitler}

Cezayir'in bağımsızlığı için Fransızlara karşı savaşan kişilerdir. Öyküde bunlar çok fazla zikredilmez.

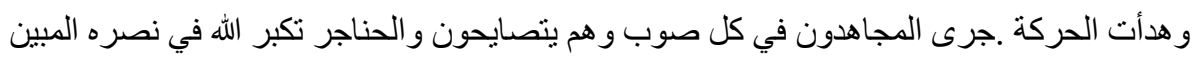

Hareket yavaşladı. Her taraftan koşan mücahitler bağrışıyor. Diller Allah'ın apaçık zaferi için tekbir getiriyor.

\subsection{6. Çocuklar}

Çocuklar, hikâyede Ayşe'yi taşlayan ve kovalayan kişiler olarak anlatılır.

تلاحقها حجارة الاطفال بين الازقة القذرة ..عيشه المهبوله .. عيثة المهبولة

Eski geçit arasında çocuklarm taşları onu izliyor.. Işse aptal... İşe aptal..

تجري عبر الطريق التحتاني لقرية تاوقريت يجري وراءها الاطفال بالحجارة .عيشة المهبولة ..عيشة المهبولة ..

Gidiyor. Tavkırit köyünün aşağı yolu boyunca gidiyor. Onun arkasından çocuklar taşla koşuyor.. Îşe aptal.. İşe aptal...

\subsubsection{Zabitalar}

Belediyenin kapısı önünde Ayşe'nin yardım istediği ve onu o mekândan uzaklaştırmaya çalışan kişilerdir.

تهرول عيشة المهبولة مستتجدة بالثنبيط امام باب البلدية او تحتمي بجدران المسجد

Belediyenin kapısı önünde zabıtalardan yardım isteyerek koşuşturuyor veya mescidin duvarlarına sı̆̆ıııyor.

فيبكين جميعا .وينشجن خلسة ..ينتهر ها الثنانبيط

Onlar topluca ağlıyorlar. Gizlice hıçkıra hıçkıra ağlıyorlar. Zabıtalar onu kovuyor.

Journal of Analytic Divinity, https://dergipark.org.tr/tr/pub/jad Volume 5/2 


\subsubsection{Huya}

Abduh'un Vietnam'da sevdiği bayan, gelişi güzel renkli elbiseler giyen, gözleri solgun ve Abduh'a sevgi besleyen kişidir.

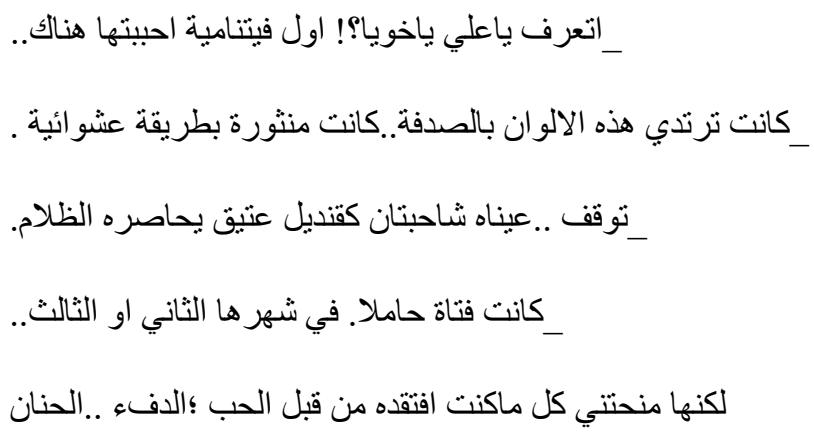

-Ey Ali, Huya 'yı bilir misin? Vietnam'da ilk sevdiğim kişiydi.

-O, gelişi güzel renkli elbiseler giyerdi. O renkler rast gele dizilmişti.

Durdu... Solgun gözleri karanlı̆̆ı kuşatan eski kandil gibiydi.

-Kız hamileydi. İkinci veya üçüncü ayıydı.

-Fakat o, özlem duyduğum muhabbeti, sevgi ve sıcakh̆̆ğ bana verdi.

\subsection{Hikâyenin Türü ve Olay Örgüsü}

Kısa hikâye, sadece birkaç sayfadan müteşekkil bir edebi tür değildir. Özellikle 19. asrın son dönemlerinde ortaya çıkan, kendine has bir takım özelliklere sahip modern bir edebiyat çeşididir. 19. asırdan önce de Batı edebiyatında kısa öykü yazma çabaları olsa da bu çabalar genellikle şekil açısından günümüz seviyesine ulaşamamıştır. ${ }^{31}$

19. asrın ikinci döneminde Guy de Maupassant'la birlikte kısa öykü anlayışı değişmiştir. Öykülerde İnsanların tecrübe ettiği veya yaşanması muhtemel olan olaylar, giriş bölümünden sonuca kadar, okuyucuda etki uyandıracak bir biçimde okuyucuya sunulur hale gelmiştir. Çehov'la birlikte ise olaylardan daha ziyade, belli bir zaman diliminde gerçekleşen olaylar karşında insanın sergilediği tavırlar ön plana çıkarılmış ve kısa öykünün çehresi biraz daha değişmiştir. ${ }^{32} \mathrm{Bu}$ iki isimden hareketle de kısa öyküler

31Turan Karataş, Ansiklopedik Edebiyat Terimleri Sözlüğ̈̈ (İstanbul: Avcı Ofset, 2001), 184.

${ }^{32}$ Karataş, Ansiklopedik Edebiyat Terimleri Sözlüğ̈̈, 184. 
genel olarak "olay (klasik vaka) öyküsü" ve "durum (kesit) öyküsü" olarak iki ana gruba ayrılmıştır. ${ }^{33}$

Bu bağlamda "Ana Vatanımızdan Hatıra Kalanlar" adlı öykünün "olay (klasik vakıa) öyküsü" türünde olduğu görülmektedir. Bu hikâyede Cezayir direnişini temsilen Abduh'un başından geçenler ve diğer kahramanlar yer almakta; olay, giriş ve gelişmenin ardından sonuçla bitirilmektedir.

Bir öykünün sağlam bir kurguya sahip olabilmesi için giriş bölümünün ardından gerilimin tırmandığı bir gelişme bölümü, bu gerilimin doruk noktasına ulaştığı bir bölüm, doruk noktasından sonra da olayların çözüme kavuştuğu ve sonuçlandığı kısım gelmelidir. ${ }^{34}$ "Ana Vatanımızdan Hatıra Kalanlar" adlı öyküde yazarın olayın ana kahramanı Abduh'u Tavgirit'in dağlarına götürmesiyle öyküye başlangıç yaptığ1 görülmektedir. Ardından sevgilisi Ayşe ile gerçekleştirdiği iç diyalog, arkadaşı Ali ile diyalogu ve Ali'nin Abduh'a "Bize doğru hareket eden bir şey hissediyorum." demesi gerilimi tırmandırmaktadır. Mücahitlerin düşmanla çatışma için makinalı tüfekleri kurmaları ve el bombalarını hazırlamaları hikâyede gerilimi doruk noktasına ulaştırmaktadır. Bu aşamadan sonra Abduh'un çatışmada şehit olması ve Ayşe'nin "Abduh sen yorgunsun... Ey sonsuz sevgi!. Rahat ol sevgilim... Ey Abdülkadir' in torunu şu an senin rolün bitmiştir." demesiyle hikâye sona ermektedir.

Bu bağlamda Amiş Abdulkâdir' in öyküyü ilgi çekici ve merak uyandırıcı bir tarzda kurguladığı ve bu noktada başarılı olduğu söylenebilir.

\subsection{Hikâyede Zaman ve Mekân}

Hikâyenin önemli unsurlarından biri de hikâyede geçen olayların zamanıdır. Hikâye incelemelerinde genel olarak zaman için, olayın meydana geldiğ i "vaka zamanı" ve yazarın olayı aktardığı "anlatma zamanı" olmak üzere iki kavram akla gelir ve incelemeler de bu eksende gerçekleştirilir. ${ }^{35}$

Yazar hikâyedeki olayların geçtiği tarihle ilgili doğrudan bir bilgi vermese de hikâyede olayın kahramanı Abduh'un Vietnam'da Huya isminde bir kıza âşık olması ve savaşmasının zikredilmesi hikâyedeki olayların 1955'ten 1962 yıllarına kadar süren bir dönemde geçtiğine işaret etmektedir. Çünkü Vietnam harbi 1955 yılında başlayıp 1975 yılına kadar devam etmiştir. ${ }^{36}$ Cezayir ise 1962 yılında bağımsızlığa kavuşmuştur. Hikâyedeki şu ifadeler olayların geçtiği tarihle ilgili ipucu sunmaktadır:

$$
\text { _اتعرف باعلي ياخويا؟! اول فيتنامية احبيتها هناك.. }
$$

\footnotetext{
${ }^{33}$ Cengiz Çalıkkılıç, Teknik ve Tematik Açıdan Tevfik el-Hakîm'in Öykücülüğü (Konya: Necmettin Erbakan Üniversitesi, Sosyal Bilimler Enstitüsü, Yüksek Lisans Tezi, 2015), 17.

${ }^{34}$ Sevim Gündüz, Öykü ve Roman Yazma Sanatı (İstanbul: Toroslu Kitaplığı, 2003), 58.

35İsmail Çetişli, Metin Tahlillerine Giriş/2: Hikâye, Roman, Tiyatro (Ankara: Akçă̆ Yayınları, 2009), 73.

${ }^{36}$ Caner Çakı vd., "Vietnam Savaşı Sırasında Çin-Abd İlişkileri: Çin Propaganda Posterleri Üzerine İnceleme", Gümüşhane Üniversitesi Elektronik Dergisi 7/2 (Eylül 2019), 954.
} 
Ey Ali (Huya)' yı bilir misin? Vietnam'da ilk sevdiğim kişiydi.

النصر يكمن في الطلقة الاولى. هكذا علمونا في حرب الفيتنام

Ilk atışta zafer olabilir. Bunu bize Vietnam harbinde öğrettiler.

Hikâye ve roman gibi edebî türleri meydana getiren en önemli ögelerden biri de mekândır. Şahısların yaşadığı ortamdan etkileneceği ve olayların vuku bulduğu yerlere göre farklı şekillere bürüneceği de bir gerçektir. Bu kapsamda hikâye ve romanda gerçek ve soyut olmak üzere iki mekân türünden bahsedilebilir. İsimlendirmeden de anlaşılacağ1 gibi somut mekân insanların yaşamlarını devam ettirdikleri gerçek yerler iken soyut mekân ise hayalî yerler olarak açıklanabilir. ${ }^{37}$

Hikâye somut mekânlarda geçmektedir. Olaylar Cezayir'in Şelf vilayetine bağlı Tavgirit beldesininin dağlarındaki Taytavin denilen bölge, Tavgirit belediye binası ve postanesinin önünde ve Vietnam'da geçmektedir.

Olayların Tavgirit ve Taytavin'de geçtiğini gösteren ifadeler:

تجري عبر الطريق التحتاني لقرية تاوقريت

Tavgırit köyünün aşă̆ı yolu boyunca gidiyor...

وتطعن زمالة طبطاوين بز غرودة منحورة ..ثم تعلن رحلتها الابدية نحو الارض و النس

Ayşe Taytavin buluşma yerini yok edici çı̆̆glklarla batırıyor. Sonra insanlara ve yere, ebedi yolculuğunu ilan ediyor.

Olayların Vietnam'da geçtiğine işaret eden cümleler:

_اتعرف ياعلي ياخويا؟! اول فيتنامية احبيتها هناك...

Ey Ali (Huya)' yı bilir misin? Vietnam'da ilk sevdiğin kişiydi.

\subsection{Dil ve Üslup}

Amiş Abdulkâdir, hikâyesini genel olarak fasih bir dille kaleme almıştır. Yazarın dilinin çoğunlukla, yalın ve anlaşılır olduğu söylenebilir. Hikâye, aşağıda örnek olarak gösterilen ifadeler gibi genel olarak kısa cümlelerden oluşmaktadır:

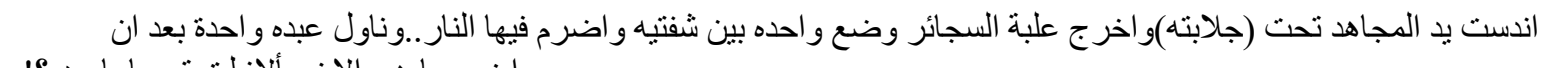

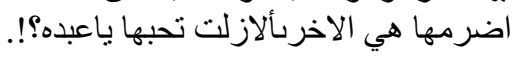

37Nurullah Çetin, Roman Çözümleme Yöntemi (Ankara: Öncü Basımevi, 2009), 133. 
Mücahidin eli gömleğinin altına girdi. Sigara kutusunu çıkardı. Bir tanesini dudă̆ının arasına koydu ve sigarasın yaktı. Bir diğerini yaktıktan sonra bir tane Abduh'a verdi. Ey Abduh onu hala sever misin?

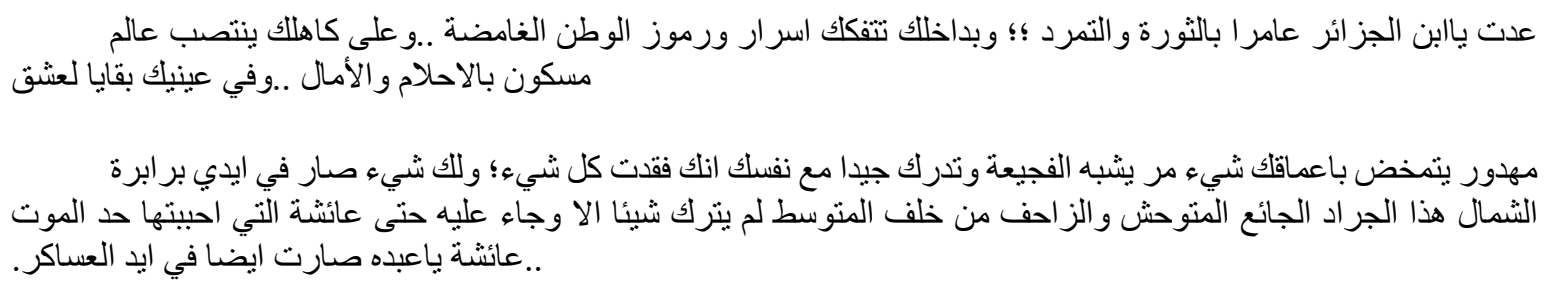

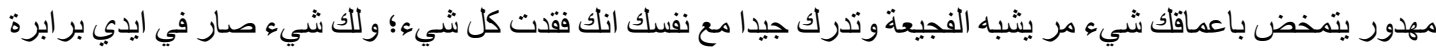

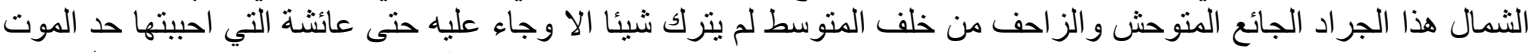
| عائشة ياعبده صارت ايضا في ايد العساكر.

Ey Cezayir çocuğu isyan ve direnişe dönüştün..... Kendi içinde vatanın anlaşılması zor sırlarını çözdün. Direnişe geçenlerin hayal ve emellerini yüklendin. Zayi edilmiş aşkın izleri gözünde görülmektedir. Vicdanında faciayı çağrıştıran acı şeyler köpürmektedir. Her şeyi kaybettiğini biliyorsun. Bir şeyin vardı. o barbar kuzeylilerin (Fransızlar) elinde. Bu aç gözlü, vahşi ve orta Avrupa'dan (Fransa) gelen çekirge hiçbir şey bırakmadı ve aldı. Ta ki ölümüne sevdiğin Ayşe'ni de...

Öyküde yer alan fiiller çoğunlukla mâzi kiptedir. Ancak özellikle farklı kahramanlar arasında geçen karşılıklı konuşmalarda doğal olarak şimdiki, geniş ve gelecek zaman ifade eden muzâri fillerin yanı sıra emir kipinde fiiller de kullanılmıştır. Öyküden alıntılanan aşağıdaki cümlelerde farklı zaman kiplerinin kullanıldığı görülecektir:

$$
\text { في ماذا تفكر ياعبده؟! }
$$

-Ey Abduh ne hakkında düşünüyorsun?

-Senin hakkında düşünüyorum!!

انت مرهق ياعبده !؟ لاتفكر في الماضي ؛انظر الى الامام تجد النصر امامك ..

Ya Abduh sen yorgun ve bitap düşmüşsün. Geçmişi düşünme ileriye bak, önünde zafer bulacaksin.

$$
\text { بامكانك ان تر اها في المستقبل.. }
$$

Ya Abduh ileride onu görebileceksin.

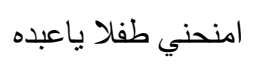

(Ey Abduh bana bir çocuk ver.

Yazarın öyküde sıkça başvurduğu anlatım tekniklerinden biri de tasvirdir. Çünkü bu yöntem hem klasik hem de modern dönemdeki yazarların dikkatini çekmiştir. Klasik dönem yazarlarından biri olan Curcânî tasvirin önemini şöyle açılar: "Kelam, sadece söz 
diziminden ibaret olursa eksik kalır. Ífade edilmek istenen şey ancak tasvir ve telifle mümkün olur. Yüzüğ̈̈n kalitesini ölçmek için sadece madenine bakılmaz. Aynca onun işçilik ve dökümüne bakılır. Bir beyti sadece anlam açısından üstün tutmamız onu söz olmak açısından mukayese yaptığımız anlamına gelmez." 38 Yani ifade de tasvir olmazsa söz çok değerli olmaz. Onun kalitesi ancak tasvirle artar.

Modern dönem ediplerinden Kutub ise tasvirin önemini şöyle açılar: "Tasvir insan tiplerini canlandırıp hayat verir, tabiatı da mücessem hale dönüştürür. Böylece hadiseler, zihinde oluşan tablolar, kıssalar ve manzaralar canl ve hareketli bir duruma gelir. Bütün bunlara bir de diyalog, karşılıklı konuşma eklenince zihinde ve hayalde tasavvur için gerekli unsurlar her yönüyle tamamlanmış olur." 39

Mehmet Tekin'e göre "tasvir etmek, bir şeyi olduğu gibi" anlatmak, çizmek değildir. Esasen bir şeyi olduğu gibi anlatmak mümkün olamaz. Romancı tasviri, tasvir edeceği şeyin karakteristik yönlerini dikkate alarak gerçekleştirir ve çizdiği, anlattığg şeyi "gerçekmiş gibi" hissettirir. En azından bunu başarmak zorundadır. Bu durumda ona düşen görev, iyi gözlemci olmak, dikkati elden bırakmamak ve ayrıntıları yakalama becerisini gösterebilmektir." $40 \mathrm{Bu}$ bakımdan tasvir bir şeyin sanatçı tarafından duyulduğu/görüldüğ̈̈ gibi aktarılmasıdır. Tasvir öznel ve nesnel amaçla yapıldığı gibi konusuna göre de değişebilir (ruhsal, fiziksel tasvir; mekân tasviri, zaman tasviri, eşya tasviri...). Tasvirler yazarın bakış açısına göre değişiklik gösterir. Örneğin romantikler gördüklerini kendi çizimleriyle ifade ederken, realistler gördüklerini olduğu gibi aktarmayı tercih etmiştirler. ${ }^{41}$

Hikâyede özellikle kişi ve mekân tasvirlerinin ön plana çıktığı söylenmelidir. Yazar kişileri tasvir ederken bazen objektif bir tasvirde bulunmakta ve gördüklerini aynen aktarmaktadir.

كانت ترندي هذه الالوان بالصدفة..كانت منثورة بطريقة عشو ائية

$O$, gelişi güzel renkli elbiseler giyerdi. O renkler rast gele dizilmişti.

عائشة ببر اءتها البدوية وقامتها الرشيقه ؛ولون الحناء الناري. و الثعر اللبلكي

Ayşe, bedevi kadın masumiyetli şık boylu, yakıcı kına rengi ve leylak renkli saçlı.

Yazar bazen de subjektif tasvire örnek olacak şekilde kendi duygu ve yorumlarını tasvirlere dâhil edebilmektedir.

\footnotetext{
38Abdulkâhir Curcânî, Delâilu'l-i'câz, thk. M. Muhammed Şakir (Kahire: Mektebetu'l-Hâncî, 2004), 254-255.

39Seyyid Kutub, et-Tasvîru'l-fennî fi'l-Kur'âni'l-Kerîm ( Kahire: Daru'ş-Şurûk, 2004).

40Mehmet Tekin, Roman Sanatı Romanın Unsurlan I (İstanbul: Ötüken Yayınları, 2018), 210.

41Jahn Manfred, Anlatıbilim Anlatı Teorisi El Kitabı, çev. Bahar Dervişcemaloğlu (İstanbul: Dergâh Yayınları, 2015), 105.
} 


$$
\text { كانت كهرة ساكنة تتحسس بالندم بعد الذي كان و انتهى }
$$

O her şey olup bittikten sonra pişmanlık hisseden kedi gibiydi.

اما عائثة فهدف..حب وموت رائع ..عائشة ياعلي مثل هذا الوطن المصادر تماما ..عائشة هي هذه التربة الظمأى؛ العامرة

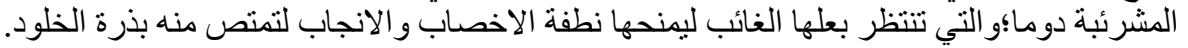

Ayşe'ye gelince, o hedef... aşk ve hoş bir ölümdür... Ya Ali! Ayşe tamamen işgal edilmiş bu vatan gibidir. Ayşe susamış bu tepe, daima başını kaldıran ev halkı, ona çocuk verecek olan kayıp kocasinı bekleyen ve ondan ebedilik tohumunu alacak olan.

.Hikâyede mekân tasvirlerinin de olduğu görülmektedir. Örneğin, و العرعار

وتوققت نظر اته فجأة . طو يلا ..داخل شكل مربع و همي من الغابات , المنكونه من اشجار البلوط الدسوسه .و الصنوبر

Uzun süre meşe, çam ve köknardan oluşan ormandaki hayali kare şekle odaklandı.

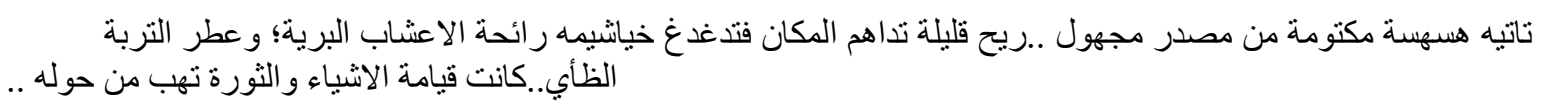

Kaynağı meçhul gizli bir hışırtı ona geliyor..... Az bir rüzgar mekana baskın yapıyor, kır kokusu ve çorak tepenin kokusu hava solungaçların okşuyordu. Çevresinde direniş ve eşyanın kıyameti kıpırdıyordu...

Yazar anlatımı daha etkin kılmak için teşbih ve istiâre sanatlarına başvurmuştur. Teşbih, aralarında bir veya birden fazla vasıfta benzerlik bulunan iki şeyin birini diğerine benzetmektir. Teşbih gizli olanı çıkarır, uzağı yakınlaştırır, soyutu somutlaştırır. ${ }^{22}$ Teşbihe örnek olarak, solgun gözler eski kandile benzetilmiştir.

Solgun gözleri karanlığı kuşatan eski kandil gibiydi.

عيناه شاحبتان كقنديل عتيق يحاصره الظلام

Diğer bir örnek, Abduh içgüdüsü dürtülenmiş yaşlı bir köpeğe benzetilmiştir,

كنت آوي الى مخدعها ككلب عجوز اعمى مدفوعا تحت غريزة بهيميه

Hayvansal içgüdüsü dürtülenmiş kör, yaşl bir köpek gibi onun yatak odasına sığındım.

Yazarın kullandığı sanatlardan bir diğeri de istiâredir. İstiâre, alakası teşbih olan mecazdır. Teşbihe dayanması nedeniyle "Müşebbehünbih ya da müşebbehten birisinin söylenmediği teşbih" şekilinde tarif edilir." 43 İstiâreli bir ifade yerinde kullanıldığında hem

42Ali Bulut, Belâgat Beyan-Meânî-Bedî̀ (İstanbul: M. Ü. İlahiyat Fakültesi Yayınları, 2019), 212.

${ }^{43}$ Nusrettin Bolelli, Belâgat Beyan-Meânî-Bedî Arap Edebiyatı (İstanbul: M. Ü. İlahiyat Fakültesi Yayınları, 2011), 90.

Journal of Analytic Divinity, https://dergipark.org.tr/tr/pub/jad Volume $5 / 2$ 
maksadı açıkça söylemekten hem de teşbihten daha etkili olup ifadeye edebi bir güzellik katar. Yine muhatabın hayal gücünün gelişmesine katkı sağlar. ${ }^{44}$ Hikâyede müşebbeh (Fransız Askerleri) zikredilmeyip müşebbeh bih " هذا الجر اد الجائع المنوحش و الزاحف gç gözlü vahşi çekirge zikredilmiştir. Fransız askerleri, vahşi her şeyi yiyip bitiren çekirgelere benzetilmiştir.

هذا الجر اد الجائع المتوحش و الز احف من خلف المتوسط لم يترك شيئا الا وجاء عليه حتى عائشة التي احبيتها حد الموت

Bu aç gözlü vahşi ve orta Avrupa'dan (Fransa) gelen çekirge hiçbir şey bırakmadı ve aldı.. Ta ki ölümüne sevdiğin Ayşeni de.

İstiâreye diğer bir örnek, Vietnam harbinin kokusu kuşa benzetilmiştir. Cümlede kuş sözcüğü zikredilmese de ifadede de uçma kelimesinin yer alması nedeniyle harbin kokusunun kuşa benzetildiği anlaşılmaktadır.

ورائحة دخان حرب فيتنام لاز الت تتطاير من بين كتقيه.

Vietham harbinin kokusu omzunda uçmaya devam ediyordu.

Yazar öyküsünü daha gerçekçi ve etkileyici bir hale sokabilmek için farklı anlatım tekniklerine de başvurmuştur. Bunlardan en çok dikkat çeken ise diş diyalog tekniğidir. Öykünün bir bölümü karakterler arasında geçen diyaloglarla örülü haldedir. Bu durum olay örgüsüne renk katmış ve farklı bakış açılarıyla olayın sergilenebilmesi fırsatını doğurmuştur. Örneğin Abduh ve Ali arasında geçen diyalog şöyledir:

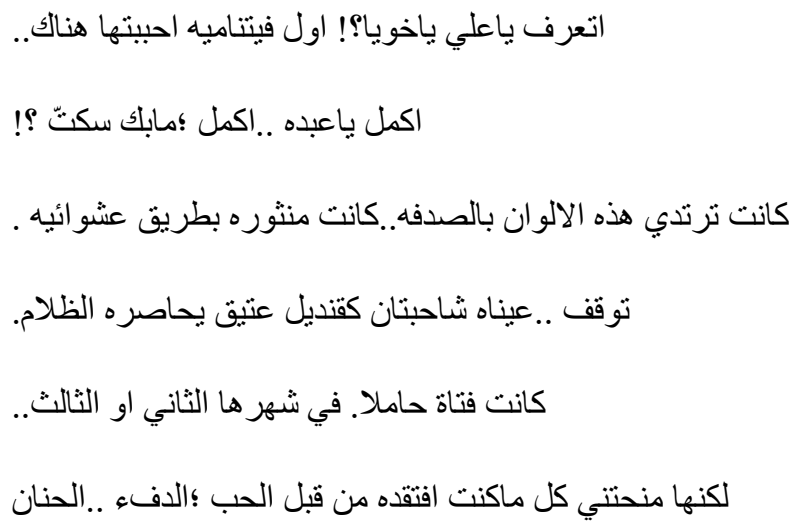

-Ey Ali (Huya)'yı bilir misin? Vietnam'da ilk sevdiğim kişiydi.

-Tamamla Ya Abduh tamamla. Seni ne susturdu? O, gelişi güzel renkli elbiseler giyerdi. O renkler rast gele dizilmişti.

${ }^{44}$ Bulut, Belâgat Beyan-Meânî-Bedî, 250. 
-Durdu... Solgun gözleri karanliğı kuşatan eski kandil gibiydi. Kız hamileydi. İkinci veya üçüncü ayıydı. Fakat o, özlem duyduğum muhabbeti, sevgi ve sıcaklığı bana verdi.

Yazar iç monolog tekniğiyle de anlatımını güçlendirmiştir. Bu teknik okuyucuya öykünün anlatıcısı konumunda olan Abduh karakterinin olaylar karşısındaki duygu ve düşünceleri hakkında daha detaylı bilgi edinebilme imkânı tanımaktadır. Örneğin Ayşé ye duyduğu özlem ve onun değerini iç diyalogla şöyle izah etmektedir.

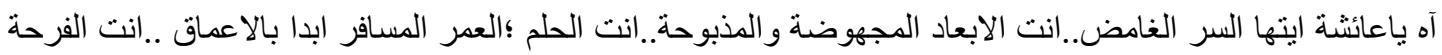

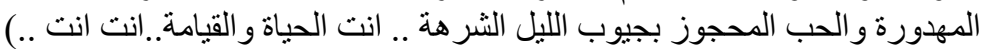

Ah Ya Ayşe! Ey gizemli sır. Sen boğazlanmış ve düşürülmüş uzaklarsın. Sen rüyasın daima uzaklara giden yolcusun, sen hedef edilmiş sevinç, gecenin içine saklanmış sevgisin... Sen hayat ve kıyametsin (sen sen...)

Yazar öykünün bazı bölümlerinde daha önceki zamanlara atıfta bulunarak geriye dönüş tekniğini de uygulamıştır. Bu yolla kişiler hakkında yeni bilgiler vermiş, öyküye canlılık kazandırmış ve okuyucuyu tek bir zamanla sınırlı tutmamıştır.

حين عاد من الهند الصينية واستحال حلمها الى حقيقة ملموسوة . علق كبير القرية أنه لم بر قط عرسا كالذي كان يومها

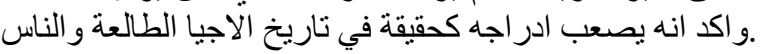

Hindistan kıtasından döndüğünde ikisinin hayalleri erişebilir gerçeğe dönüştü. Köyün büyüğ̈̈ senin dü̆̆̈̈nün gibisini görmediğini söyledi. Önceki nesil ve insanlarda böyle bir düğünün muhtevasını düşünmenin çok zor olduğunu belirtti.

\section{Sonuç}

Amiş Abdulkâdir, ülkemizde tanıdık bir yazar olmamasına rağmen Modern Cezayir Edebiyatında öykü, roman ve şiir alanında eser veren yazarlardan biridir. Müellifin eserlerinde ele aldığı konular, ağırlıklı olarak Fransızlara karşı yapılan Cezayir direnişi ve diğer İslam coğrafyalarındaki işgalci güçlere karşı yapılan mücadelelerdir. Ayrıca ülkesinde 1980 yılında meydana gelen deprem ve islamafobi, annesinin vefatına hüznü konuları da yer almaktadır.

Yazarın "Ana Vatanımızdan Hatıra Kalanlar" adlı hikâyesi öykü olay/klasik vaka türünde kaleme alınmıştır. Fasih bir dille kaleme alınan öyküde cümleler genelde basit ve anlaşılır niteliktedir. Genelde tahkiye edici/öyküleyici bir anlatım dili benimsenmiştir. Dış diyalog tekniği başta olmak üzere iç monolog, betimleme ve geriye dönüş gibi anlatım teknikleri de yazarın sıkça başvurduğu ve öyküsündeki anlatımı zenginleştirdiği başlıca unsurlar olmuştur.

\section{Kaynakça}

Abdulkâdir, Amiş. Kıssatu't-tıfl fi'l-Cezâir dirâse fi'l-hasâis ve'l-mezamîn. Cezayir: Dâru'l-Ğarb, 2003.

Journal of Analytic Divinity, https://dergipark.org.tr/tr/pub/jad Volume 5/2 
Journal of Analytic Divinity, Cilt/Vol: 5, Sayı/Issue: 2, 2021, ss/pp 74-96.

Kanâdîlu'z-zalâm. Hervan: Daru'1-Ğarb, 2004.

ez-Zemenu's-sa'b. Hevran: Dâru'l-Ğarb, 2003.

Beyâzu'l-yakîn. Vehrân: Menşûrâtu'l-Dâri'l-Edîb, 2006.

Sukût... el-Ârife İzabel tetehaddes. Tizi Vuzu: Dâru'l-Emel lit-Tibâ'a

Ve'n-Neşr, 2019.

'Avâü's-sadâ. Vehrân: Dâru'l-Ğarb, 2004.

Afven... seahmil kaderî ve esîr. Tizi Vuzu: Dâru'l-Emel lit-Tibâ'a Ve'n-Neşr, 2012.

Abdelkader, Amiche. "es-Sîratuz'-Zâtiyyetu'l-i̇lmiyye li'l-Ustâz Abdulkâdir Amiş". Facebook. 8 Mayıs 2021, 23:30. Erişim 9 Mayıs 2021.

http://www.facebook.com/abdelkader.amicge.9

Afad, T.C. İçişleri Bakanlığı Afet ve Acil Durum Yönetimi Başkanlığı Deprem Dairesi Başkanlığı "10 Ekim 1980 Cezayir Depremi”. Erişim 16.01.2021. https:/ / deprem.afad.gov.tr/tarihteBuAy?id=45

Araz, M. Kılay. “Cezayir Edebiyatında Kısa Öykü”. Nüsha 20/50 (Haziran 2020), 168.

Baktıaya, Adil. “1830: Fransa'nın Cezayir'i İşgali, Abdülkâdir'in Yükselişi ve Amerikan Kamuoyunda Abdülkâdir Hayranlığgı". Ortadoğu Etütleri 1/2 (Ocak 2010), 147.

Bâtûl, Arcûn. Abdulkâdir Amiş fì beyâzi'l-yakîn min rivayeti't-tecrübe ilâ rivâyetit-tecrîb. Cezayir: el-Câhiziyyetu's-Sekâfiyyetu'l-Cemiyye, 2008.

Bolelli, Nusrettin. Belâgat Beyan-Meânî-Bedî Arap Edebiyatı. İstanbul: M. Ü. İlahiyat Fakültesi Yayınları, 2011.

Bulut, Ali. Belâgat Beyan-Meânî-Bedî. İstanbul: M. Ü. İlahiyat Fakültesi Yayınları, 2019.

Caner Çakı vd. "Vietnam Savaşı Sırasında Çin-Abd İlişkileri: Çin Propaganda Posterleri Üzerine İnceleme". Gümüşhane Üniversitesi Elektronik Dergisi 7/2 (Eylül 2019), 954.

Curcânî, Abdulkâhir. Delâilu'l-i'câz. thk. M. Muhammed Şakir. Kahire: Mektebetu'lHâncî, 2004. 
Çalıkkılıç, Cengiz. Teknik ve Tematik Açıdan Tevfík el-Hakîm'in Öykücülü̈̆̈̈̈. Konya: Necmettin Erbakan Üniversitesi, Sosyal Bilimler Enstitüsü, Yüksek Lisans Tezi, 2015.

Çetin, Nurullah. Roman Çözümleme Yöntemi. Ankara: Öncü Basımevi, 7. Basım, 2009.

Çetişli, İsmail. Metin Tahlillerine Giriş/2: Hikâye, Roman, Tiyatro. Ankara: Akçă̆ Yayınları, 2. Basım, 2009.

DİB, Diyanet İşleri Başkanlığı "Sabra ve Şatilla Katliamı". Erişim 16 Ocak 2021. https://www.diyanethaber.com.tr/sabra-ve-satilla-katliami-resimleri,59.html

Gündüz, Sevim. Öykü ve Roman Yazma Sanatı. İstanbul: Toroslu Kitaplığı, 2003.

Gökgöz, Turgay. Modern Cezayir Edebiyatı. İstanbul: Akdem Yayınları, 2019.

Hizmetli, Sabri. “Osmanlı Yönetimi Döneminde Tunus ve Cezayir' in Eğitim ve Kültür Tarihine Genel Bir Bakış". Ankara İlahiyat Fakültesi Dergis i32 (1991), 15-16.

Karataş, Turan. Ansiklopedik Edebiyat Terimleri Sözlü̈̆ü. İstanbul: Avcı Ofset, 2001.

Kutub, Seyyid. et-Tasvîru'l-fennî fi'l-Kur'âni'l-Kerîm. Kahire: Daru'ş-Şurûk, 17. Baskı, 2004.

Küçüksarı, Mücahit. "Suriyeli Öykücü Sa'îd Hûrâniyye ve Ahî Rafîk (Ağabeyim Refik) Adlı Kısa Öyküsü". Necmettin Erbakan Üniversitesi İlahiyat Fakültesi Dergisi 50/50 (Ocak 2020), 57-80.

Manfred, Jahn. Anlatıbilim Anlatı Teorisi El Kitabı. çev. Bahar Dervişcemaloğlu. İstanbul: Dergâh Yayınları, 2015.

Parıldı, Metin. "Fransız Sömürgeciliği Döneminde Kuzey Afrikada Arap Dili ve Edebiyatına Genel Bakış". Bilimname 18 (Ocak 2010), 116-117.

eş-Şerku'l-Evsat Cerîdetu'l-Arabi'l-Duveliyye. "Devriyyât" (30 Kasım 2003). https://aawsat.com

et-Tahrîr. "el-UstâzAmiş Abdelkâdir li't-tahrîr" (20 Eylül 2014), 17. http://www.altahrironline.com/ara/

Tekin, Mehmet. Roman Sanatı Romanın Unsurları I. İstanbul: Ötüken Yayınları, 2018.

Wikipedia Özgür Ansiklopedisi "Şelf Vilayeti". Erişim 16 Ocak 2021. https://tr.wikipedia.org/wiki/\%C5\%9Eelf_Vilayeti 
Journal of Analytic Divinity, Cilt/Vol: 5, Sayı/Issue: 2, 2021, ss/pp 74-96.

“Dâiratu't-Tavgirît". Erişim 16 Ocak 2021 https://ar.wikipedia.org/wiki/Dâiratu't- Tavgirît

Youtube. "Profesör Amiş Abdulkâdir fî Hissat likâi'l-Ma'rife bi'l-Kanâti'lVataniyyeti'l- Cezâiriyye". Yayın Tarihi 9 Kasım 2014. https:/ / youtu.be/1Yo7lG5DMg4 (Erişim 20 Mart 2021).

“ Profesör Amiş Abdulkâdir el-Cuz 4”. Yayın Tarihi 13 Temmuz 2011. https:/ / youtu.be/ XB0mKPXWZwU (Erişim 20 Mart 2021). 